\title{
Research Paper \\ Comparison of the Effect of Child-Parent Relationship Therapy (CPRT) and Parent Management Training (PMT) on Nutritional Problems in children 3 to 6 years
}

\author{
Mahsa Shirini Bonab ${ }^{1}$, Parisa Sadat Seyed Mousavi ${ }^{* 2}$, Leili Panaghi ${ }^{3}$ \\ 1. M.A. in Family Therapy, Family Institute, Shahid Beheshti University, Tehran, Iran \\ 2. Assistant professor, Family Institute, Shahid Beheshti University, Tehran, Iran \\ 3. Associate professor, Family institute, Shahid Beheshti, Tehran, Iran
}

Citation: Shirini Bonab M, Seyed Mousavi PS, Panaghi L. Comparison of the effect of child-parent relationship therapy (cprt) and parent management training (pmt) on nutritional problems in children 3 to 6 years. Quarterly Journal of Child Mental Health. 2020; 6(4): 85-96.

\section{http://dx.doi.org/10.29252/jcmh.6.4.9}

\section{A R T I C L E I N F O}

\section{Keywords:}

Parent management training, child-parent relationship therapy, nutritional problem

Received: 5 mar 2019 Accepted: 20 Nov 2019 Available: 3 Mar 2020

\section{A B S T R A C T}

Background and Purpose: Proper nutrition plays an important role in the brain and cognitive, emotional, and social development of children. Eating problems in preschool and primary children are common and need to be treated. Therefore, the purpose of this study was to compare of the effect of child-parent relationship therapy (CPRT) and parent management training (PMT) on nutritional problems in children 3 to 6 years

Method: This is a quasi-experimental study with two experimental and one control group. The sample consisted of 75 mothers of 3 to 6 year old children with nutritional problems in Tabriz in 2017 who were selected by convenience sampling and randomly assigned into three groups including 2 experimental and 1 control group. Child Eating Behavior Questionair (Warle, Guthrie, Sanderson, Rapport, 2001) was used for data collection. Parent management training was performed in six 90minute sessions and child-parent relationship therapy in ten 2-hour sessions. Follow-up was also performed one month after the intervention. Data analysis was performed using mixed betweenwithin subject ANOVA with SPSS 20 software

Results: The results of data analysis showed that there was a significant difference between the three groups in terms of eating problems. Both interventions reduced eating problems, but the parental training program had more efficacy in reducing both components of eating problems, namely, food intent(within group factor $\mathrm{P}=0.001, \mathrm{~F}=818.84$ and between group factor $\mathrm{P}=0.001, \mathrm{~F}=31.32$ ) and food avoidance (within group factor $\mathrm{P}=0.001, \mathrm{~F}=1237.56$ and between group factor $\mathrm{P}=0.001, \mathrm{~F}=47.86$ ). Conclusion: Based on the findings of this study, it can be concluded that the parent management training program can improve the inappropriate behaviors between mother and child by improving the parenting skills and behavioral strategies. Child-parent relationship therapy has also improved eating disorders by establishing a secure attachment relationship and meeting emotional needs.

\footnotetext{
* Corresponding author: Parisa Sadat Seyed Mousavi, Assistant professor, Family Institute, Shahid Beheshti University, Tehran, Iran. E-mail addresses: P_mousavi@sbu.ac.ir
} 


\section{مقايسه تأثير مداخله مبتنى بر بهبود رابطه والد - كودك و آموزش مديريت والدين بر مشكلات تخذيهاى كودكان ب تا ح سال

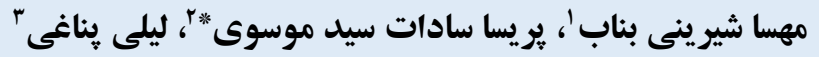

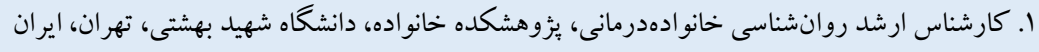

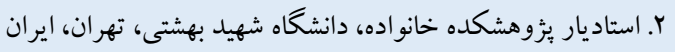

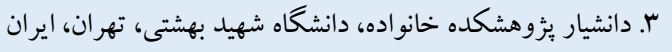

زمينه و هدف: تغذيه مناسب در تحول مغزى و شناختى، عاطفى، و اجتماعى كود كان نقش بسيار مهمى دارد. مشكلات خوردن در كود كان

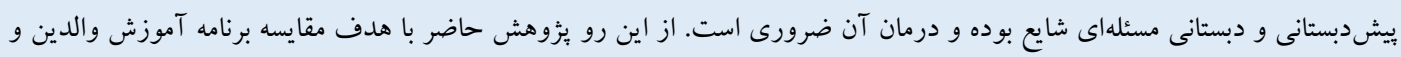
درمان رابطه والد و كود كك بر كاهش مشكلات خوردن كود كان س-4 سال انجام گرفت. روش: اين ئوهش از نوع شبه آزمايشى بادو گروه آزمايش و يك گروه گَ اه است. نمونه مورد مطالعه VD نفر از مادران كود كان داراى

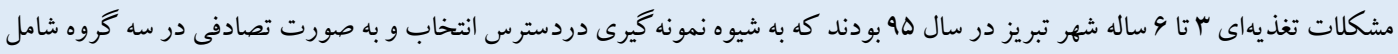
r گروه آزمايش و ا گروه گ اه قرار جايدهى شدند. براى جمع آورى دادهها از يرسشنامه رفتار خوردن كود كان (وارل، گاترى، ساندرسون

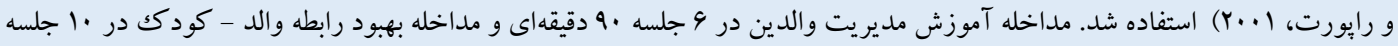

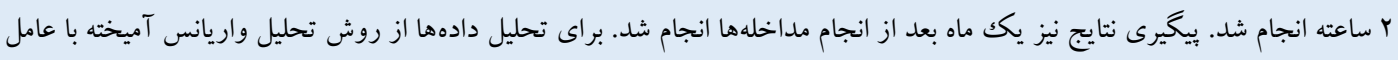

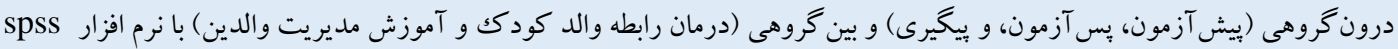
20 يافته ها: نتايج تحليل دادها نشان داد كه بين سه گروه از نظر مشكلات خوردن تفاوت معنىدار وجود دارد. هر دو مداخله، مشكلات خوردن را كاهش دادند، اما برنامه آموزش والدين اثربخشى بيشترى در كاهش هر دو مؤلفه مشكلات خورددن يعنى كرايش

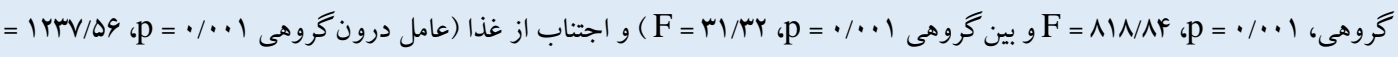
نت نتيجه كيرى: بر اساس يافتهاى اين مطالعه مىتوان نتيجه گرفت كه برنامه آموزش مديريت والدين با افزايش دانش و مهارت والدگرى والدين و آموزش راهكارهاى رفتارى به آنها، رفتارهاى معيوب بين مادر و كودكك را اصلاح كرده و از اين طريق به بهبود مشكلات خوردن

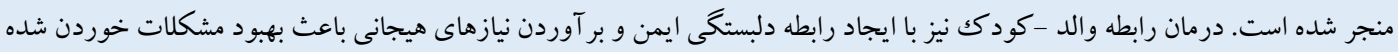

مشخصات مقاله 
همجنين مطالعات، آموزش مر اقب را به عنوان عاملى آشكار در مداخلات

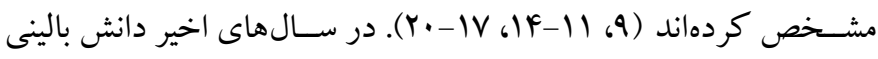

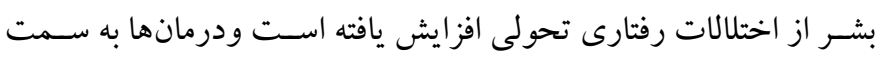

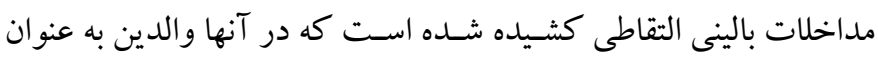
عضو فعال در درمان كود كان خود مطرح هستند (Y) (Y). در مورد مشكلات تغـذيـهاى نيز، رابطه بين والد و كودكك به ويزه مادر عامل بســيار مهم و

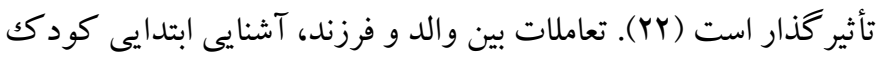

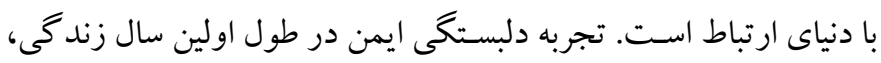

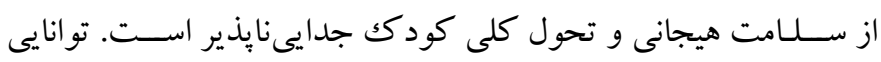

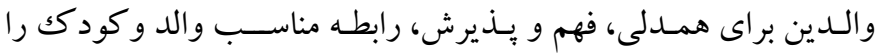

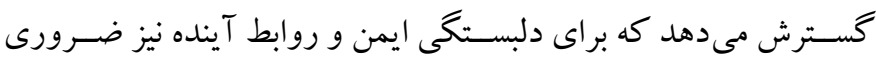

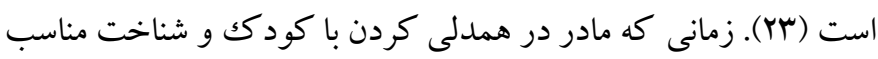

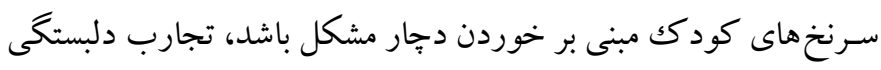

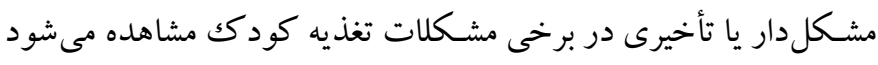

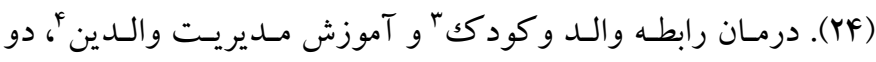
مداخله روانشـناختى هسـتند كه با آموزش به مراقب كودك به اصـلاح رابطه والد و كود كك مى يردازند.

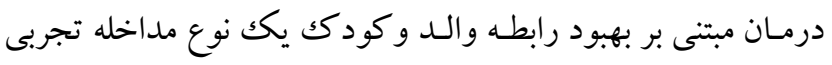

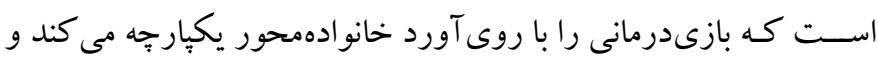

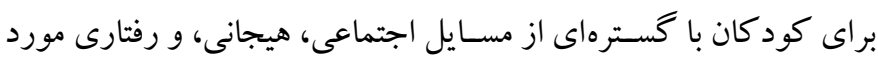

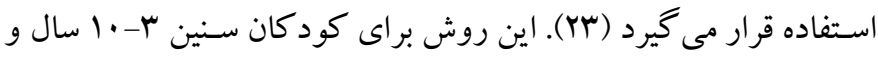

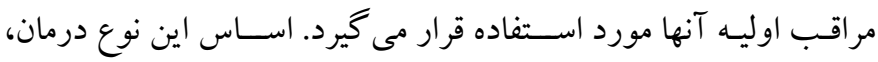
آموزش برخى اصول بازىدرمانى به مراقبان كودك است. بازى، يكى از از

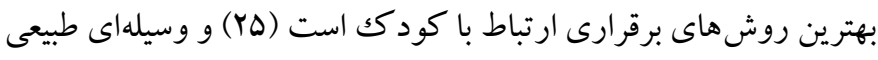

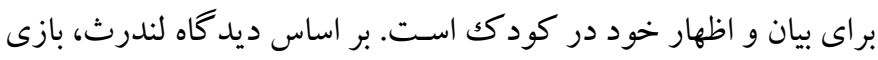
كردن براى كودكك مسـاوى اسـت باصحبت كردن بر ایى يكك بزر گسال

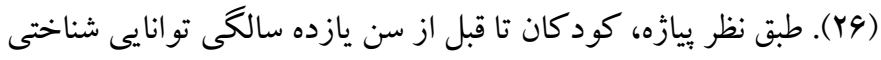

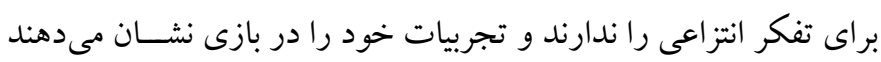

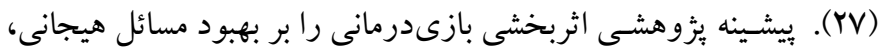

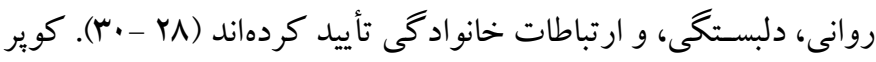

مقلدمه

كود كـان بخش عمــدهاى از جمعيـت جهـان را تشــكيـل مىدهند. لزوم شـناخت صسحيح اين قشـر از جمعيت جهان و كوشـش به منظور سلامت جسـمانى و روانشـاختى آنها بر همخان روشـن اسـت. سالهاى ييش از دبستان نقش اسـاسى در تحول و سازشيافتكى كود كان در آينده دارد (1). اين سـنين به ويزٔه در رفتارهاى خوردن سالم حائز اهميت است. اين دوران فرصستى منحصسر به فرد براى ايجاد رفتارهاى خوردن سـالم براى كل زند اختلالات تغذيه' ، عارضه جدى سلامت هستند كه در طول زندگى بر

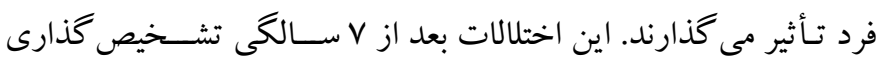
مىشـوند و قبل از آن به عنوان مشـكل تغذيه ؟ مطرح مى شوند (Y). رفتار خوردن سالم به رشد مناسب در وزن، قد و اندازه دور سر منجر شده (r) ، و از سـو ءتغذيه، كندى رشد، مشكلات تغذيهاى حاد، مشكلات سلامتى طولـانى مـدت و حـادى مـانتـد بيمارىهاى قلبى عروقى، ديابت نوع دو، سـرطان، جاقى، بيمارى قلبى اسـتئو بروسـيس، كاهش رشــ استخوانى به علت دريافت كلسيم پيايين و بيمارى اسكوربوت، جلو گيرى مى كند (F) V). مشـكلات تغذيه شــامل مجموعه رفتارهايى اسـت كه غذا دادن به كودكك را دشــوار كرده و رابطسه مـادر و كودكك را تحست تـأثير قرار مى دهند و در نتيجه، موجب نكرانى مادر مىشوند. مشكلات غذا خوردن شـامل كم غذا خوردن و خوردن انواع معدودى از غذاها، اجتناب از غذا خوردن، بحـث و جـدل هنگحام غـذا خوردن، و رفتـارهـاى مثبت والدين (مانند تشويق والدين در هنگام غذا خوردن) هستند (^). مداخلات مختلفى روى مشكلات تغذيهاى كود كان انجام شده است. اين مــاخلـات شــامـل مـداخلـات رفتارى، مداخلات تغذيهاى، خانواده درمانى، بازىدرمانى، و آموزش مراقب هسـتند. مداخلات رفتارى شـامل روشهـايى مـانند مهار محرك،، خاموشــى، حســاســيتزدايى منظمم ، شـكـلددهى، مـديريست مشــروط، و توجه انتخابى (9 و · (1)؛ مداخلات تغذيهاى شــامل آموزش صـحيح تغذيه، دســكارى هاى اشـتها، و برنامه سازمانمند وعده غذايى (9، || - ها )؛؛ و مداخلات روانشناختى نيزشامل بـازىدرمانى، خانو ادهدرمانى، و آموزش روانى هســتند (سا، 19 و IV).

1. Nutritional disorder

2. Nutritional problem 


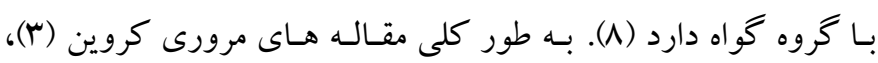

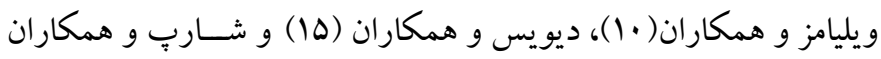

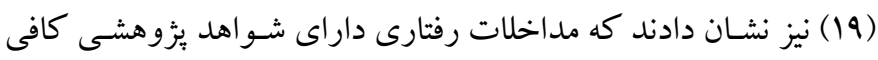

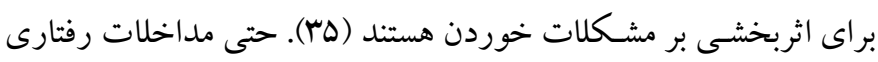

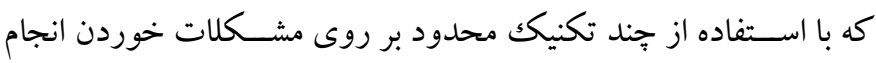

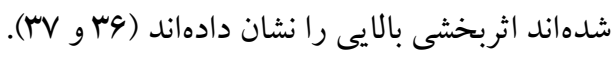

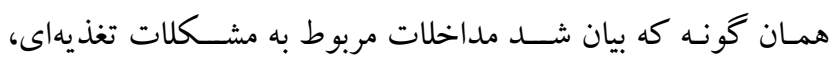

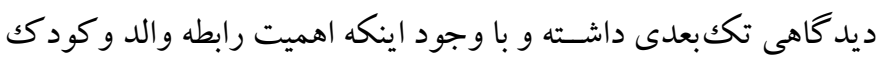

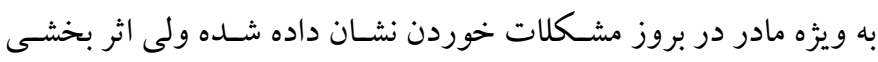
مـداخلـات رابطهمحور مانند درمان رابطه والد وكودكك براتون و لندرث

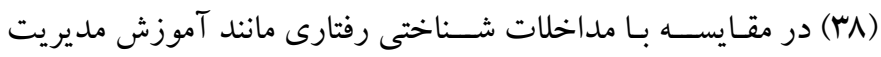

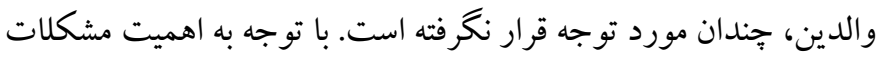

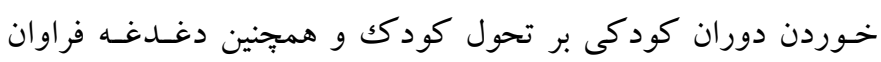

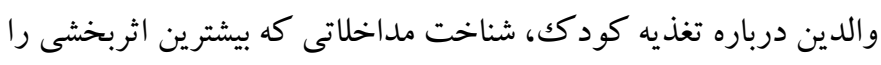
در اين زمينه داشـته باشـند، ضرورى به نظر مىرسد. علاوه بر اين با بهبود سلامت روان كودكان، سلامت روان والدين و خانو اده نيز بهبود يابد، زيرا

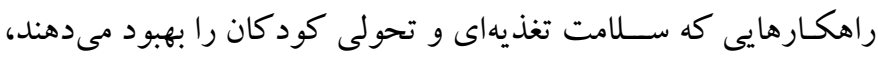

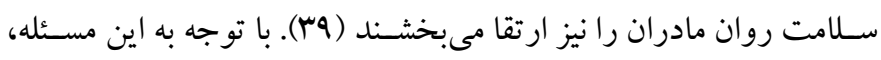
هدف اين يثزوهش مقايسه اثربخشى دو روش درمان شـناختى رفتارى و

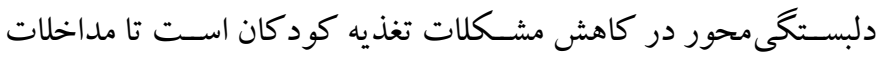
داراى اثربخشى بالا شــاسـيى شده و براى كود كان و و الدين آنها مورد استفاده قرار گيرد.

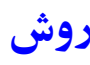
الف) طرح هئوهش و شر كت كنند كان: روش يزوهش نيمه آزمايشى با

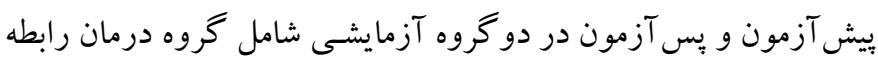

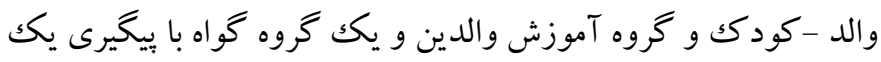

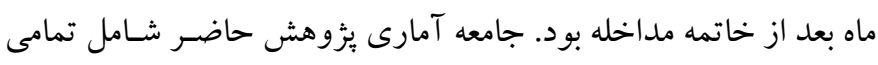

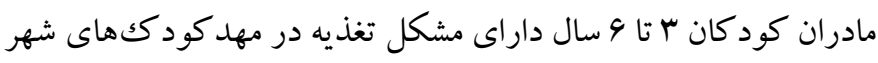

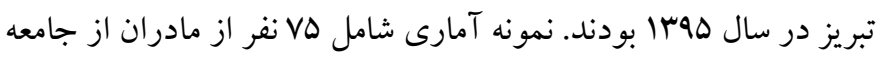

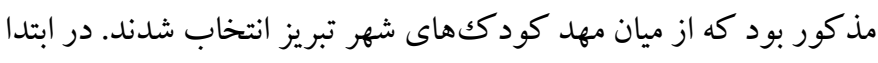

و همكاران نيز نشــان دادند كه بهبود رابطه مادر -كودكك موجب بهبود مشـكلـات غذا خوردن مى شــود، ولى يا اين وجود دادههاى محدودى دربـاره اثربخشـى روش هـاى مبتنى بر رابطسه مـادر وكودكك در بهبود مشكلات غذا خوردن وجود دارد (اس).

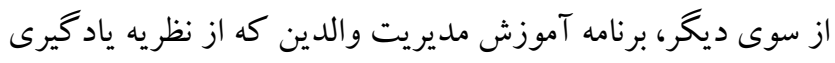

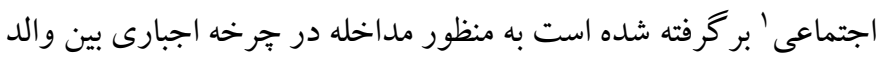
وكود كك ايجاد شده است. اين برنامه مداخلهاى رده سنى بيش دربستانى تا

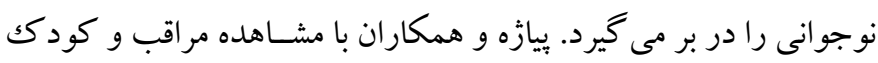

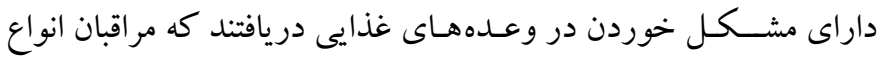

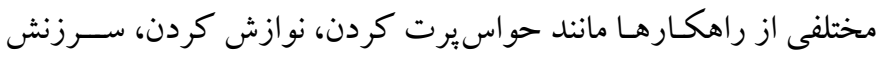
كردن، اجـازه بـه كودكك براى ايجـاد وقفـه در حين غذا خوردن، و و تهيه

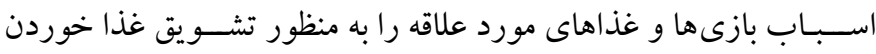

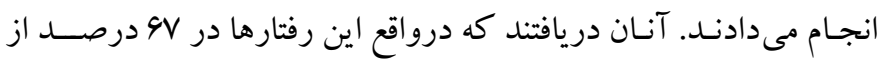

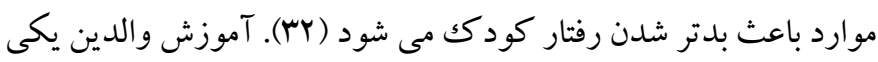
از جامع ترين بسته هاى مداخلهاى شناختى رفتارى است كه در آن بسيارى

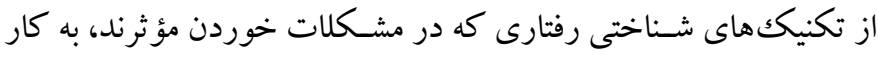
كرفته مىشـوند. تكنيك هايى مانند توجه مثبت، اصسول تشـويق، اصسول

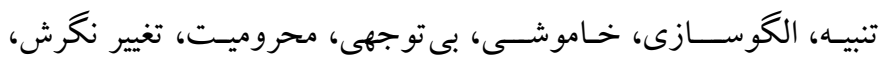

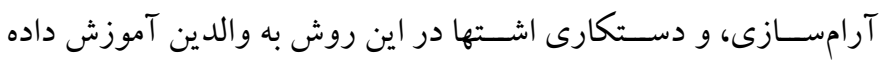

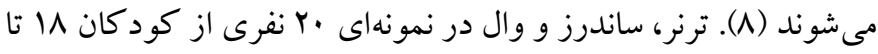

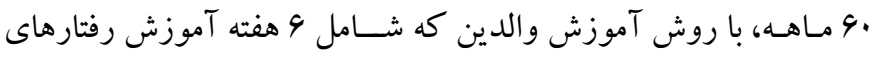

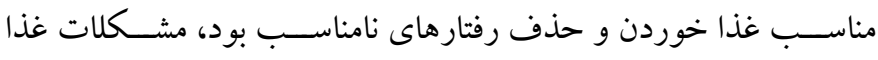

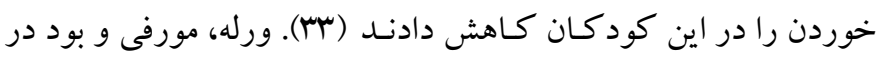

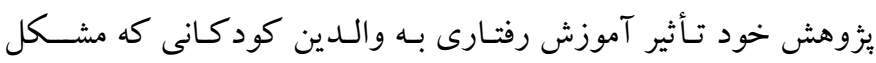
اجتناب از غذا داشستند، مو رد مطالعه قرار دادند. نتايج يزووهش نشـان داد كـه آموزش رفتـارى والـدين موجب كاهش مشــكلات غذا خوردن در

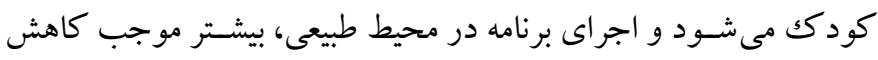

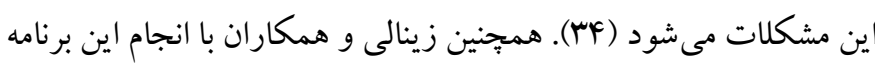

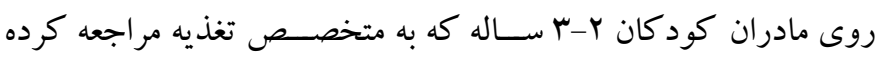
بودند، نشان دادند كه آموزش والدين در زمينه نحوه رفع مشكلات تغذيه كود كان، كاهش معنىدارى در مشكلات غذا خوردن كودكك در مقايسه

1. Social learning theory 
ا.برسسشنامه رفتار خوردن كودكان ': اين يرسشنامه توسط وارل، گاترى،

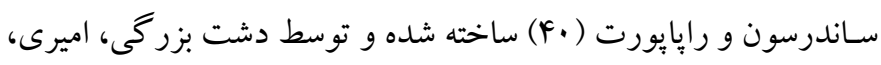

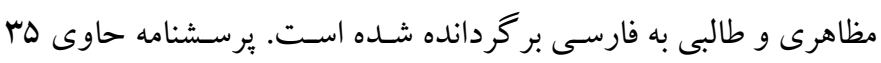

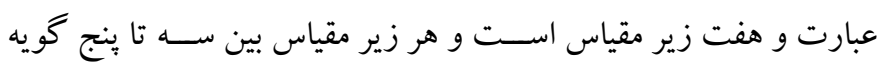

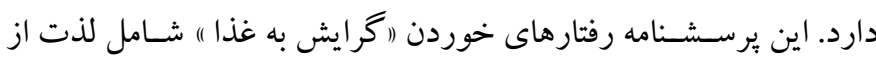
غذا، تمايل به نوشــيدنى، و يرخورى هيجانى؛ و (اجتناب ازغذالها) شــامل

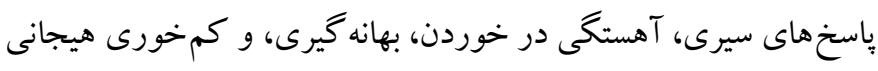

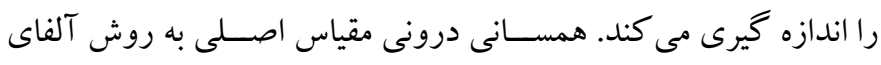

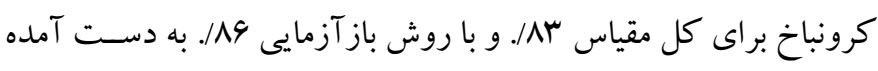

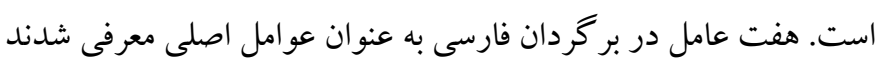

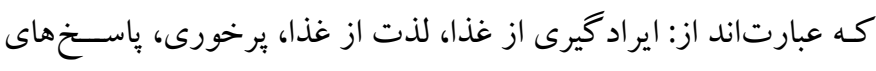

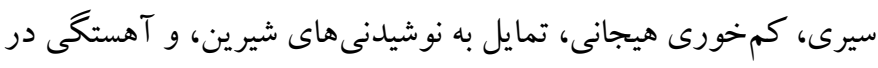

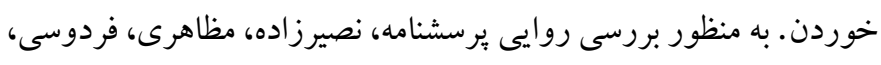

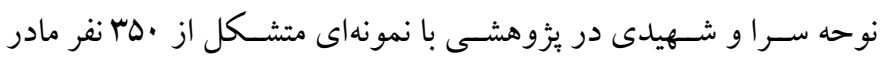

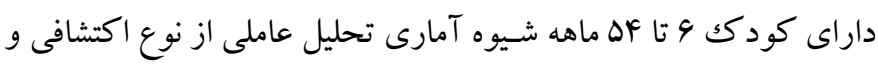

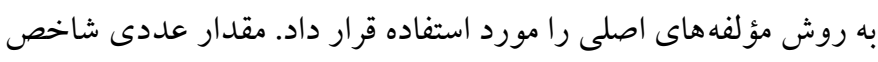

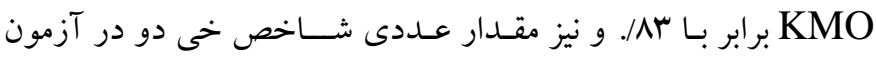

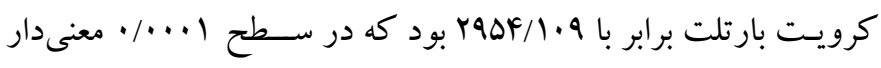

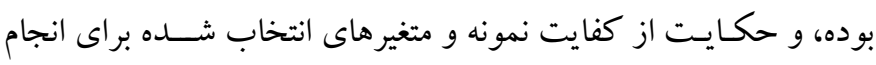

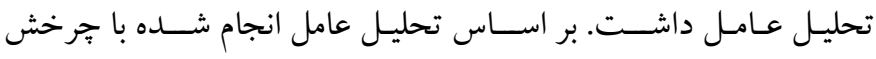

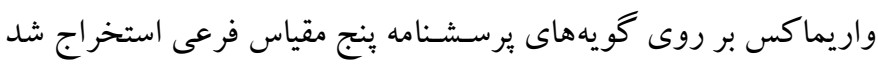

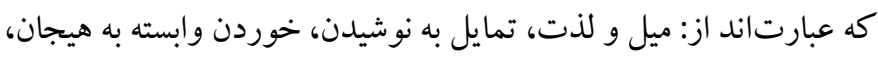

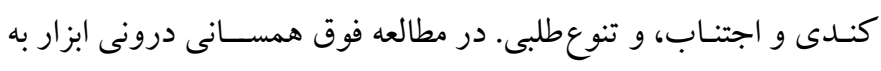

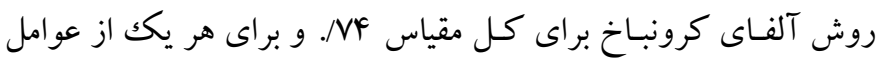

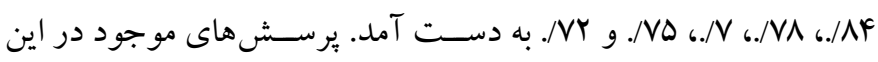

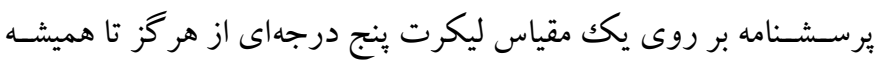
درجهبندى مىشـوند و به هر عبارت از صـفر تا جهار نمره داده مى شـود.

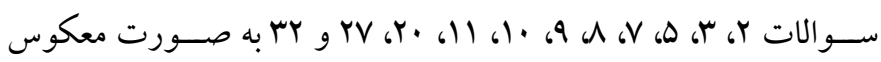
نمره گذارى مىشـوند و جمع نمرات برسـش هاى هر خردهمقياس، نمره

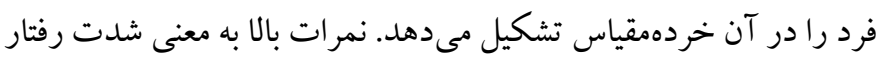
كود كك در مقياس مورد نظر است (r) (Y).
Vهد كودكك از مناطق او Y به طور در دسـترس انتخاب شــند. در اين

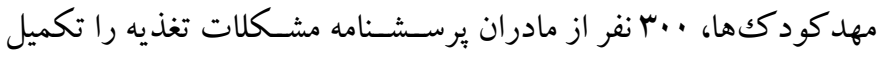

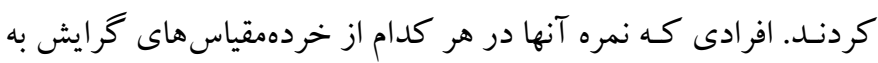

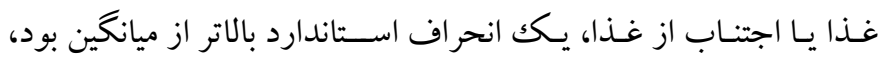

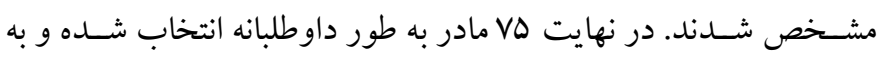

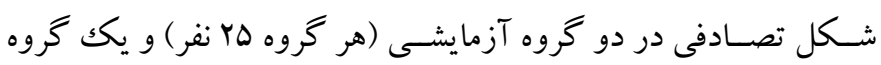
كواه (br نفر ) جايدهى شدند.

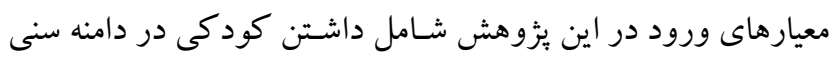

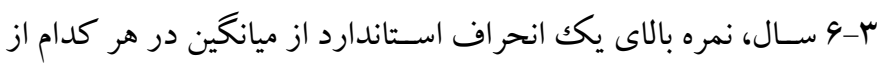

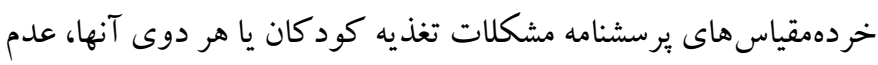

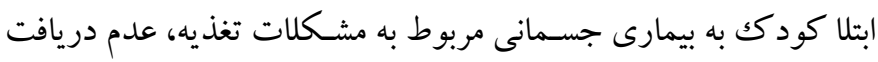

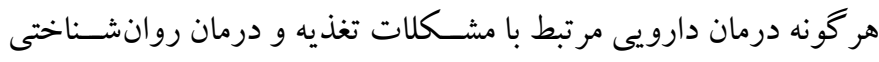

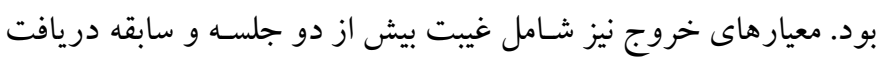
درمان روانشـناختى و دارويى توسط مادر بر اساس گز ارش خود او او بود.

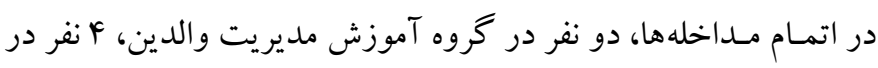

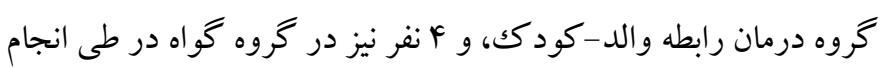

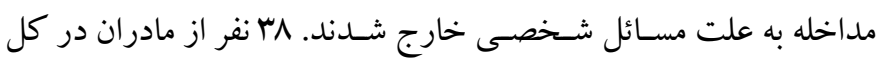

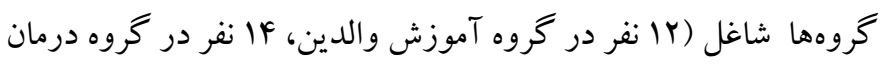

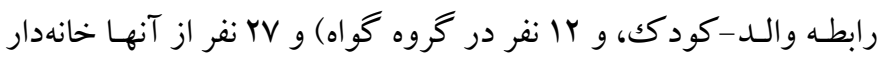

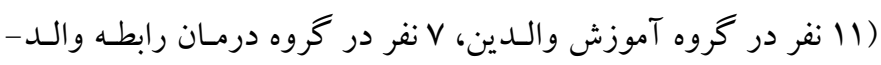

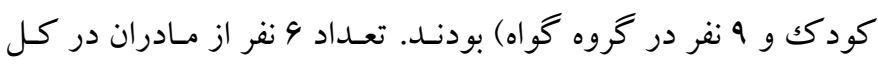

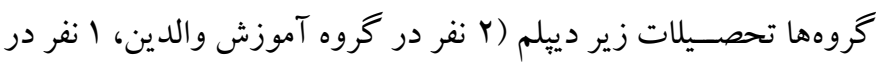

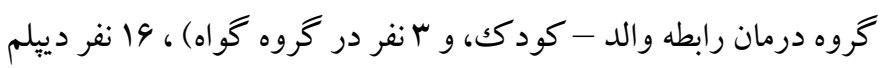

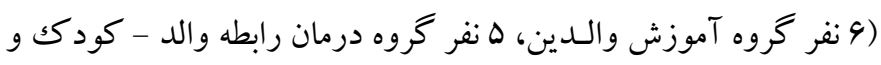

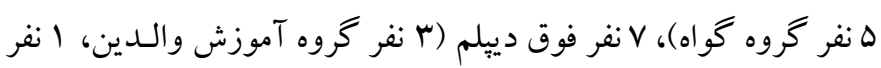

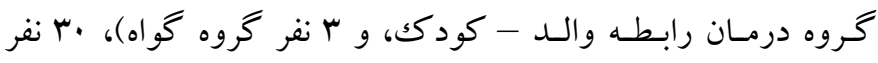
كارشناسى (1)

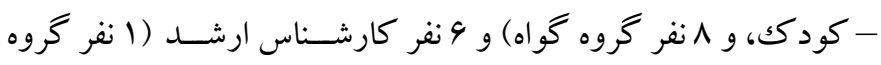

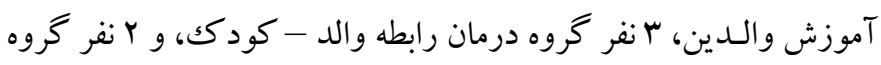

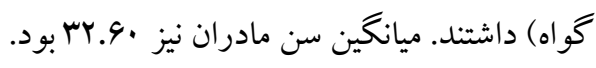

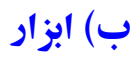

1. Child eating behavior questionair 
رابطه والد - كودكك براسـاس كتاب راهنماى اين روش و كتاب كار آن

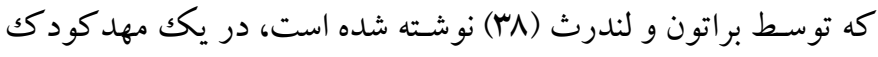

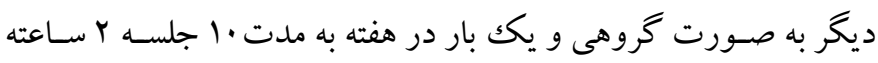

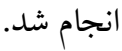

ج) برنامه مداخلهاى: برنامه آموزش والدين در مطالعه حاضـر بر اساس

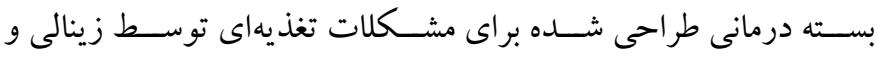

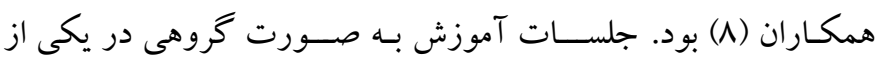

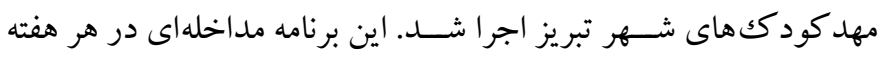

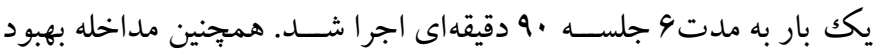

جدول ا: جلسات درمان آموزش مديريت والدين و درمان رابطه والد و كودك دو

\begin{tabular}{|c|c|c|c|c|}
\hline \multicolumn{2}{|l|}{ درمان رابطه والد و كودكى } & \multicolumn{2}{|c|}{ آموزش مديريت والدين } & \multirow{2}{*}{ جلسه } \\
\hline محتوا & هدف & محتوا & هدف & \\
\hline 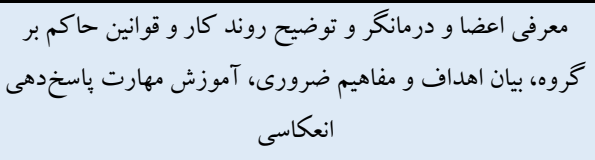 & آموزش بِاسخ انعكاسى & $\begin{array}{c}\text { ارائه مطالبى درباره خوردن، آموزش تكنيك دستكارى اشتها } \\
\text { دون }\end{array}$ & اصلاح نگرش مادر درباره & 1 \\
\hline 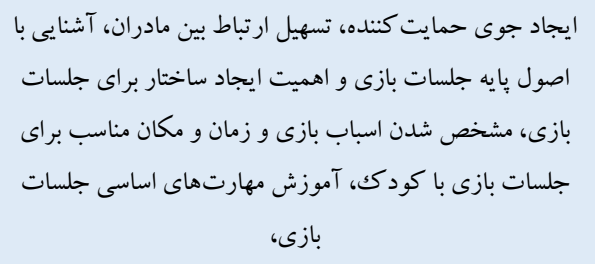 & آموزش قوانين اساسى & 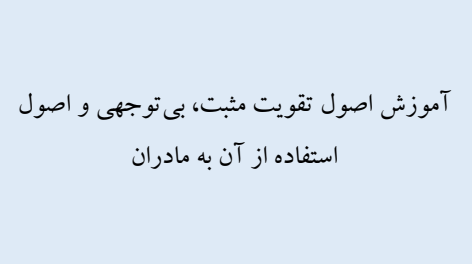 & آموزش تكنيك توجه مثبت & r \\
\hline 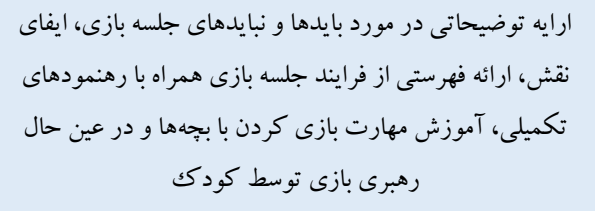 & آ آموزش مهارت هاى & آموزش اصول اقتصاد زتونى و كاربرد آن و توجه & يادگيرى تكنيك اقتصاد زتونى & $r$ \\
\hline 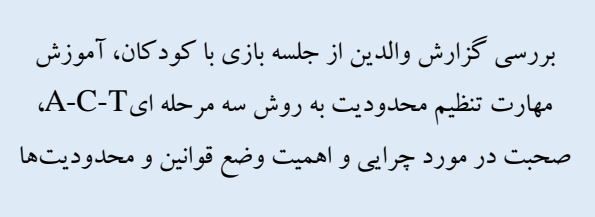 & بر ب برى روند جلسات & 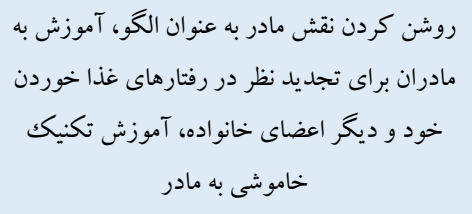 & نسبت به وعدههاى غذايى نغيى مادران & f \\
\hline بررسى گزارش والدين از جلسات بازى، مرور مهارت تنظيم & مرور و اصلاح آموزههاى & آموزش روش تنبيهى و اصول مربوط به آن & آموزش روشهاى تنبيه به مادران & $\Delta$ \\
\hline بر بايدهاى جلسات بازى و و آموزين از جلسات بازى، تهيه يوسترى از بايدها و & $\begin{array}{c}\text { آموزش مهارت دادن حق انتخاب } \\
\text { انق }\end{array}$ & 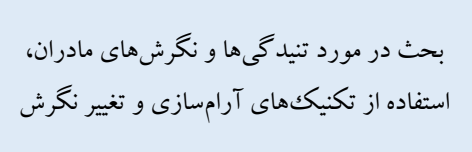 & آموزش تكنيكهاى آرامسازى & 9 \\
\hline 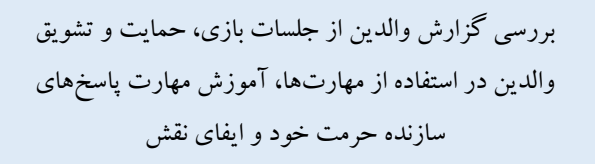 & 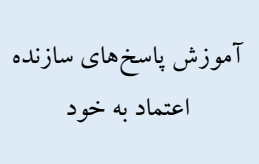 & & & $v$ \\
\hline بررسى گزارش والدين از جلسات بازى، آموزش مهارت تشويق & ياد گيرى مهارت تشويق & & & $\wedge$ \\
\hline و بر بلدين در استفاده از مهارت والدين از جلسات بازى آموخته شده، آمويق و حمايت مهارت & يادگيرى مهارت تنظيم & & & 9 \\
\hline 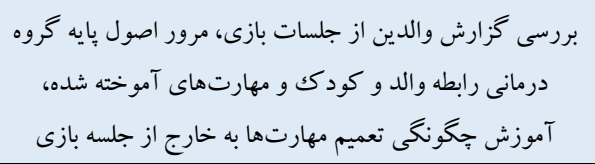 & مرور موارد آموخته شده & & & 1. \\
\hline
\end{tabular}


و از هر گونه تبعيض اجتناب شد. در نهايت گروه گو اه در فهرست انتظار

$$
\text { براى دريافت مداخله قرار گرفتند. }
$$

در اين مطالعه به منظور تجزيه و تحليل دادهها در بخش آمار توصيفى مرافي

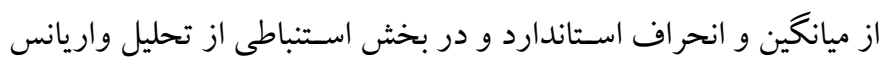

$$
\text { آميخته استفاده شد. }
$$

\section{يافتهها}

براى انجام تحليل واريانس، ييشفرض نرمال بودن توزيع متغيرها توسط

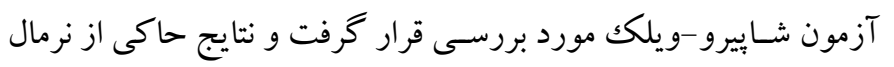
بودن توزيع متغيرها بو د. در جدول زير، شـاخص هاى توصسيفى به همراه

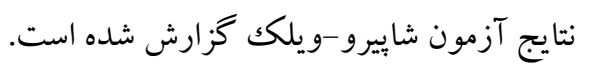

د) روش اجرا: به منظور انجام مداخلات در مهدكودككها، از ســازمان

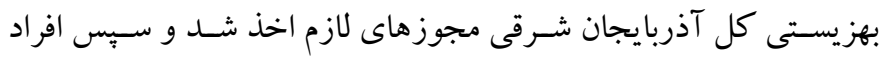

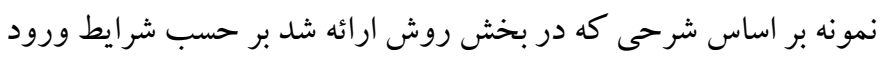

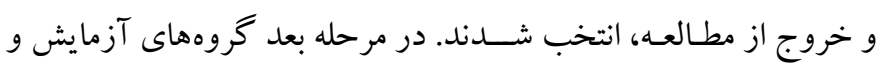

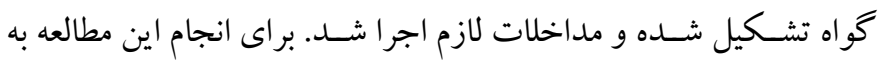

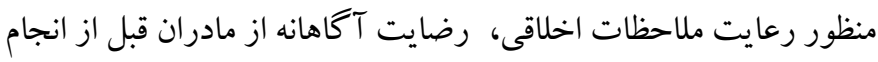

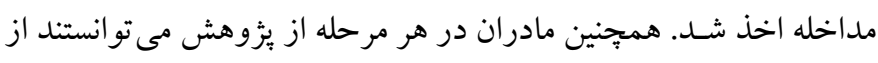

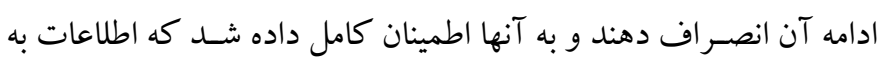

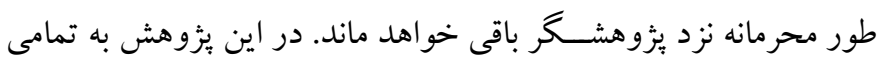

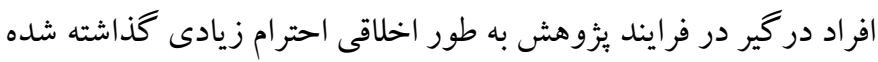

\begin{tabular}{|c|c|c|c|c|c|c|c|}
\hline سطح معنى دارى & آماره شإييرو-ويلك & انحراف استاندارد & ميانكين & تعداد & كروه & وضعيت & متغير \\
\hline .1 .98 & $\cdot /$ /AY & $9 / M T F$ & $r V / F \wedge$ & rr & آموزش والدين & \multirow{3}{*}{ ي بيش آزمون } & \multirow{8}{*}{ كر ايش به غذا } \\
\hline . & - $/ 9 \Delta F$ & $r 9 / \Delta \wedge 1$ & $r V / v I$ & r & درمان رابطه والد و كودك & & \\
\hline 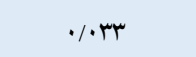 & $\cdot / \wedge Q \Lambda$ & $F / r \cdot 9$ & $r a / r q$ & $r$ & كواه & & \\
\hline.$/ 11$ & . /qr. & $r / \Delta l$. & $r \cdot / r q$ & rr & آموزش والدين & \multirow{3}{*}{ 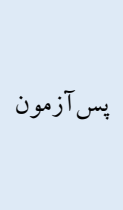 } & \\
\hline.$/ 991$ & •/991 & $\Delta / F \Delta \Lambda$ & $\mathrm{rV} / \mathrm{q}$. & r & درمان رابطه والد و & & \\
\hline . $/ k r$ &.$/ 9.4$ & $F / T \Delta 1$ & $r q / / F$ & r & كواه & & \\
\hline . &.$/ 9.8$ & $r / A \cdot V$ & rY/NF & rr & آموزش والدين & \multirow{3}{*}{ يبيخيرى } & \\
\hline$\cdot r \cdot r$ & -/A\&\& & $91.4 \mathrm{~F}$ & $r \cdot N 1$ & r & درمان رابطه والد و & & \\
\hline 年 & $\cdot / 9 \cdot r$ & $F / F \mid q$ & $r a / r \Lambda$ & r & كواه & & \multirow{10}{*}{ اجتناب از غذا } \\
\hline$\cdot / N \wedge 9$ & - /qVF & $8 / 9.9$ & $k q /, q q$ & rr & آموزش والدين & \multirow{3}{*}{ بيش آزمون } & \\
\hline$\cdot / F \mid F$ & 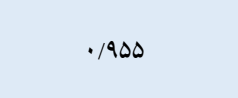 & $\Delta / 1 \Delta F$ & $F \Delta / F \wedge$ & Y & درمان رابطه والد و & & \\
\hline$\cdot / \Delta 49$ &.$/ 994$ & 每/ & $\$ 9 / \pi T$ & r & كواه & & \\
\hline$\cdot / M 9$ & - /qYa & $r / r \cdot r$ & re/rg & r & آموزش والدين & & \\
\hline$\cdot \pi \cdot r$ & . /AQV & $\Delta / . r$. & $r \Delta / \cdot \cdot \cdot$ & rI & درمان رابطه والد و & بِ آزمون & \\
\hline 吾 & . /qvo & $r / T r V$ & $r \Delta / \cdot \Delta$ & $r$ & كواه & & \\
\hline$\cdot / / \Delta \mathrm{V}$ & $\cdot / 9 \mathrm{~V}$ & r/a9V & $r q / r q$ & rr & آموزش والدين & \multirow{3}{*}{ ييخيرى } & \\
\hline$\% . \Delta v$ & ./911 & $F / N \Delta V$ & rN/YF & r & درمان رابطه والد و & & \\
\hline.$/ \Delta 4 \Lambda$ & . /q94 & r/IYY & $\$ 9 / \mu_{1}$ & $r$ & گواه & & \\
\hline
\end{tabular}

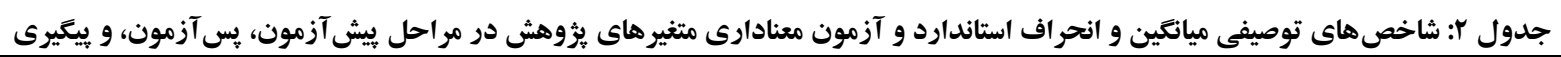


در جدول ب اثربخشسى دو روش آموزش والدين و درمان رابطه والد

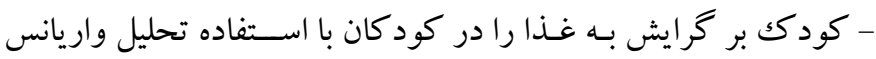
آميخته نشان مى دهد.

جدول بّ: نتايج تحليل واريانس آميخته براى رفتار كرايش به غذات

\begin{tabular}{|c|c|c|c|c|c|c|}
\hline مجذور اتا & سطح معنى دارى & مقدار F & ميانكين مربعات & درجه آزادى & مجموع مربعات & منبع تغيير \\
\hline . /9r. & $\cdot / \cdots 1$ & NIN/AYG & $I F V \cdot N \cdot r$ & r & $r q F I / F \cdot F$ & اثر زمان \\
\hline \multirow[t]{2}{*}{$\cdot / 1990$} & $\cdot / \cdots 1$ & YGF/YGI & FVF/grV & f & INQN/DFV & اثر متقابل زمان×گروه \\
\hline & & & 1/V99 & IrF & TrYMID & خطاى زمان \\
\hline
\end{tabular}

از آن بود كهه ميزان گرايش به غذا در گروه درمان رابطه والدو كودك

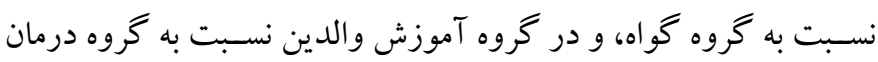

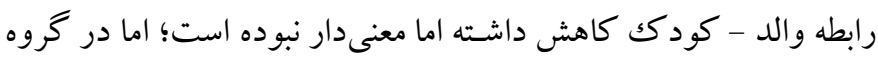
آموزش والدين نسبت به گروه گ اهو، كاهش معنى دار وجود داشته است.

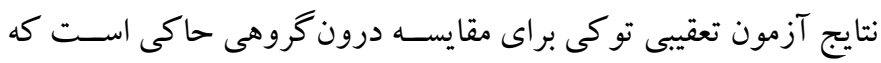

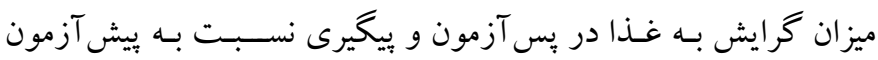

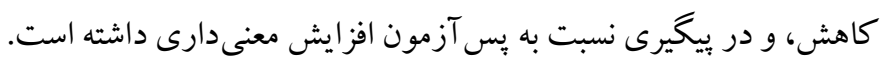
در جـدول \& اثربخشـى دو روش آموزش والدين و درمان رابطه والد كودكك بر اجتناب از غذا در كود كان گز ارش شده است.
نتايج تحليل واريانس آميخته براى رفتار گُ ايش به غذا نشـان داد كه

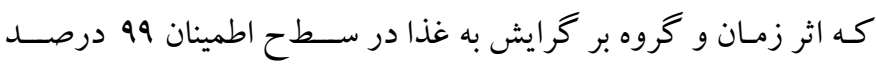

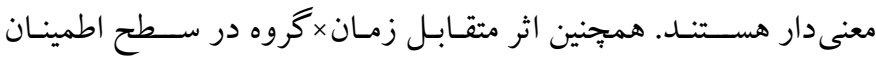

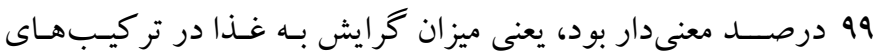

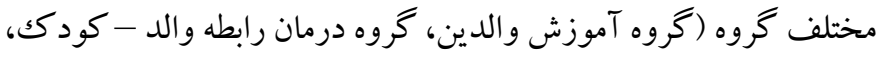

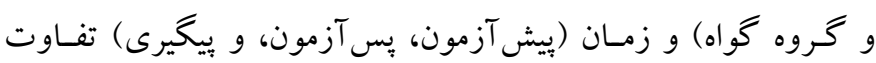

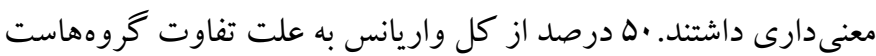

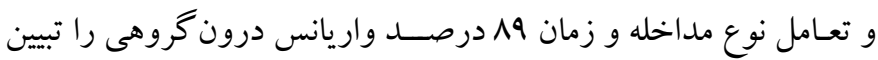
مى كند. همجِين نتايج آزمون تعقيبى توكى براى مقايسـه بين گروهى حاكى

جدول ع: نتايج تحليل واريانس آميخته براى رفتار اجتناب از غذا

\begin{tabular}{|c|c|c|c|c|c|c|}
\hline مجذور اتا & سطح معنىدارى & مقدار F & ميانكين مربعات & درجه آزادى & مجموع مربعات & منبع تغيير \\
\hline . $/ 9 \Delta r$ & $\cdot / \cdots 1$ & $I Y T V / \Delta \Delta V$ & IVre/D.r & r & $M F V / \cdots \Delta$ & اثر زمان \\
\hline$\cdot 19 \cdot v$ & $\cdot \cdots \cdot 1$ & FV/AGT & rq.r/qIV & r & $\Delta r \cdot V / A r F$ & اثر خروه \\
\hline \multirow[t]{3}{*}{.$/ 919$} & $\cdot / \cdots 1$ & $r r \Delta / q \cdot r$ & FVI/TYV & f & $1 M \Lambda \Delta / r \cdot q$ & اثر متقابل زمان×گروه \\
\hline & & & $1 / 4 \cdot r$ & IrF & IVr/aqr & خطاى زمان \\
\hline & & & $\Delta F / F \cdot F$ & ar & $M T V / \cdot I V$ & خطاى گروه \\
\hline
\end{tabular}

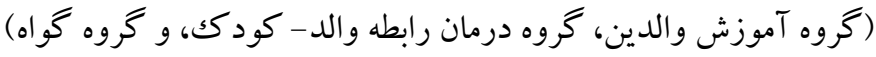
و زمان (ييش آزمون، يس آزمون، و يِخيرى) تفاوت معنى دارى داشــتند. نوع مداخله •4 درصسـد واريانس بين گروهى و تعامل نوع مداخله و زمان ا9 درصـد واريانس درون گروهى را تبيين مى كند. نتايج آزمون تعقيبى
نتايج تحليل واريانس آميخته براى رفتار اجتناب از غذا نشـان داد كه اثر زمان و كروه بر اجتناب از غذا در سـطح اطمينان 99 درصسد معنىدار

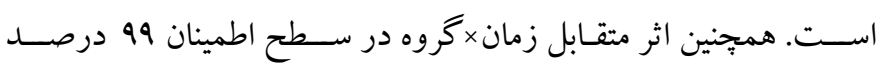
معنى دار اســت، يعنى ميزان اجتناب از غذا در تر كيبهاى مختلف كروه 
خوردن نسبت به گروه گواه داشته است. بين دو گروه مداخله در اجتناب

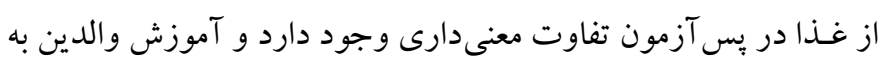

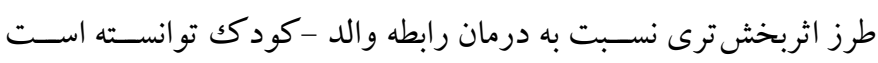

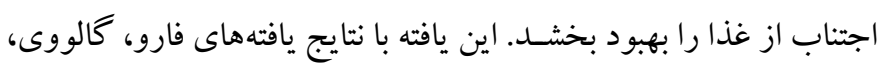

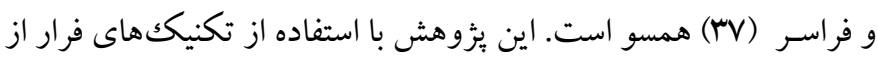

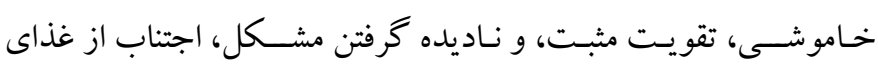

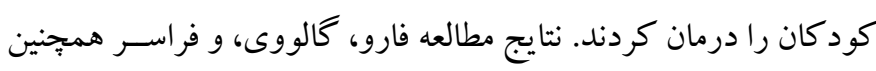

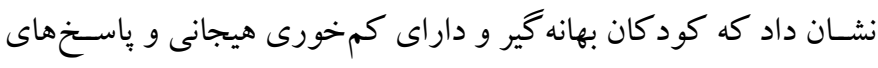
سيرى درونى، بيشتر از سـاير همشير هاى خود تحت فشار والدين براى

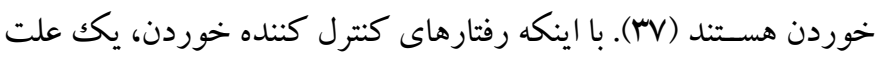

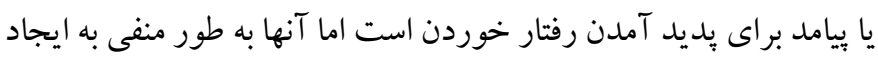

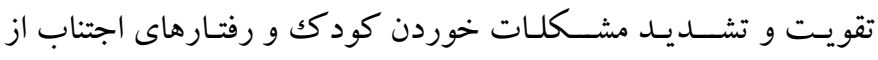

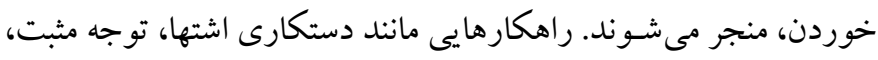

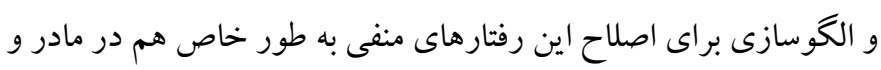

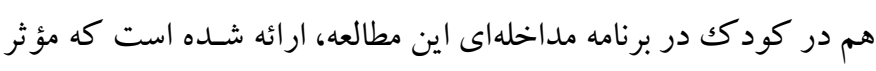

به طور كلى آموزش مديريت والدين هردو مؤلفه مشـكلات خوردن

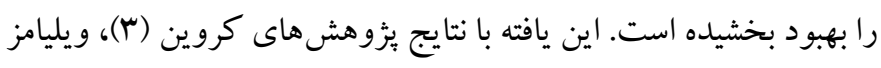

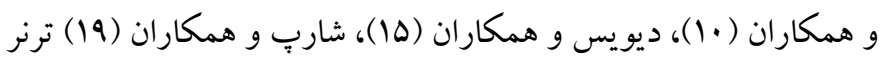

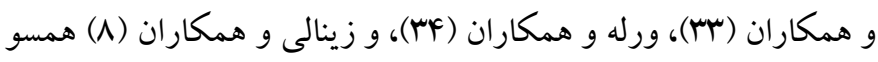

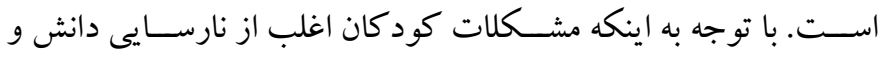

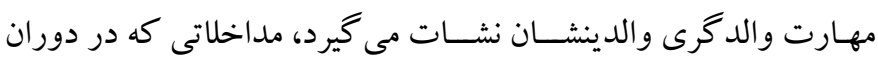
يُش دبستانى بر شناخت والدين تمركز مى كنند، اثربخشى بالايى را نشان

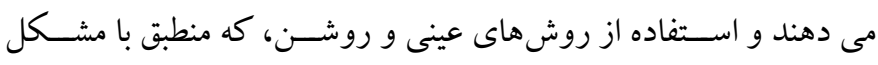

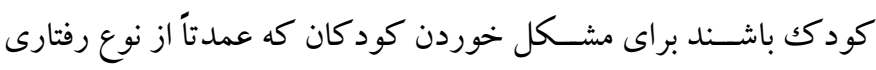

$$
\text { است، اثربخشتر هستند. }
$$

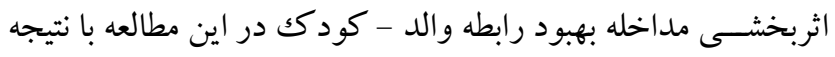
يزّوهش كوير و همكاران همسـو اســت. تجارب خور ردن مشـكل دار يا

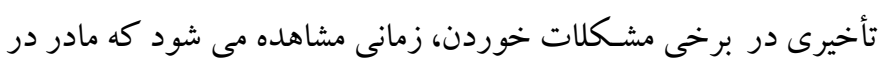

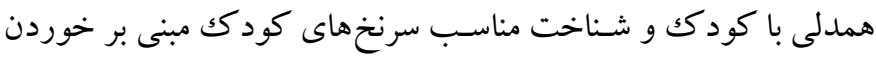

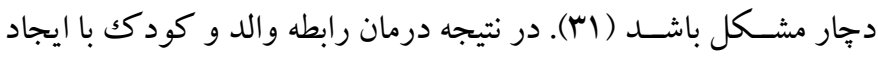

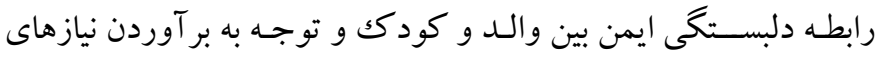

تو كى براى مقـايسـه بين گروهى حاكى از آن بود كه اســت كه ميزان

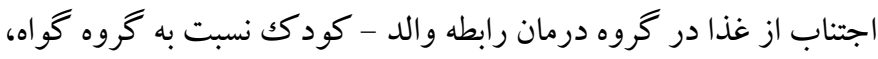

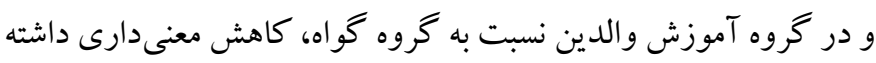

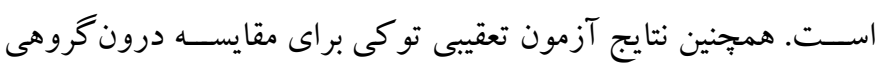

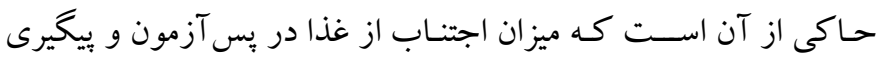

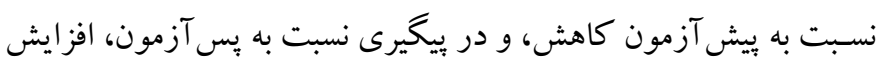

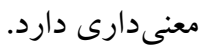

\section{بحث و نتيجه كيرى}

هدف از انجام يزوهش حاضـر مقايسه اثربخشى برنامه آموزش والدين و و وكي

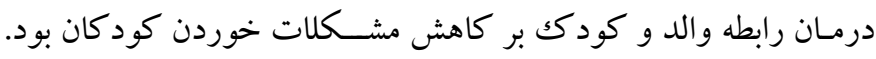

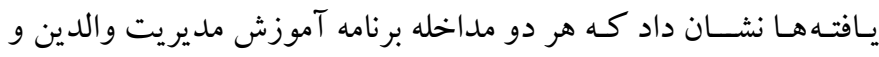
درمان رابطه والد -كودكك به طور معنادارى بر كاهش مشكلات خوردن اثربخش بودهاند، اما آموزش والدين اثربخشى بيشترى در كاهش هر دو مؤلفه مشكلات خوردن يعنى گرايش به غذا و اجتناب از غذا داشته است.

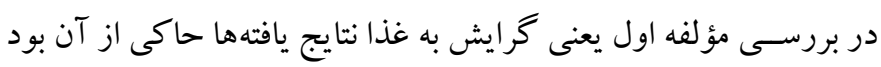

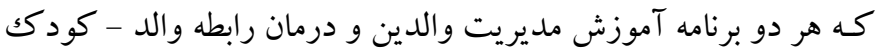

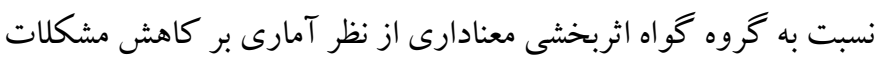

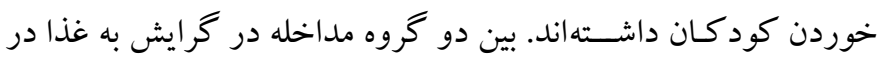
يس آزمون تفـاوت معنى دارى وجود دارد و آموزش والـدين بـه طرز

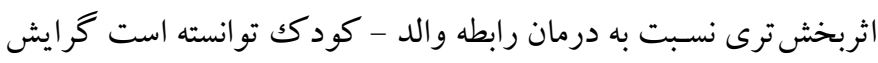
به غذا را بهبود بخشــــ مى تو ان با اسـتفاده از نتايج اين مطالعه و مطالعات ديخر اين كونه تبيين كرد كـه رفتارهاى اشـتباهى كه به منظور ترغيب

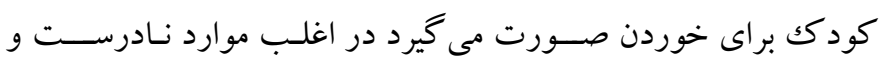

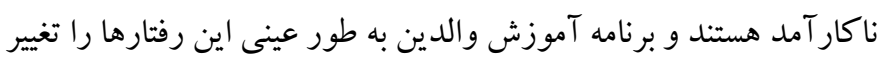

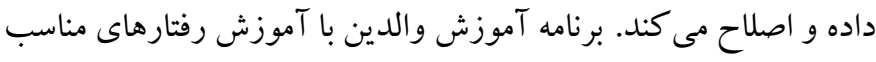

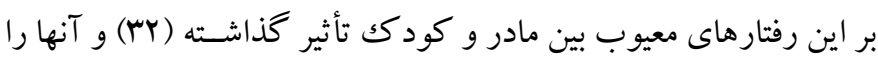
اصلاح كرده و گرايش به غذا را افزايش داده است.

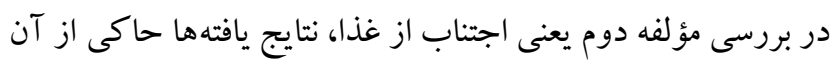

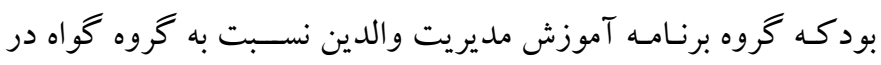
مشكلات خوردن كاهش بيشترى از لحاظ آمارى داشـته است. همجنين

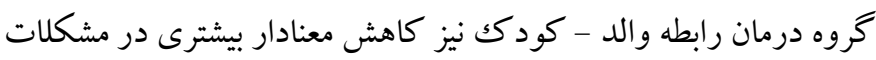


عوامل ريشهاى و همبحنين اصلاح رفتارهاى ثانويه معيوب به بهبود مشكل خوردن كودكان كمـك كنند، ولى در انتخاب نوع مداخله شــايد للازم باشـد بررسى بيشترى روى مشكلات ارتباطى والد و كود كك انجام شود.

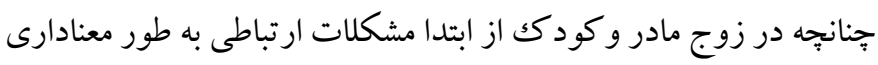

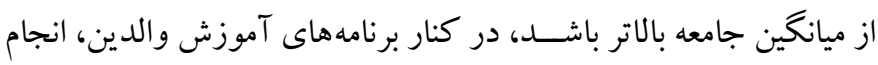
مداخلات مبتنى بر اصسلاح روابط والد و كودكى نيز ضـرورى يا حداقل مفيد به نظر مىرسد. اين بزووهش بـا برخى محـدوديتهاى روش شـــناختى نيز همر اه بود.

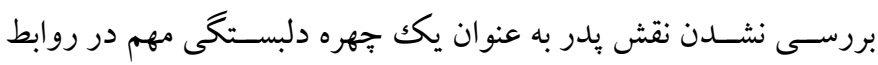

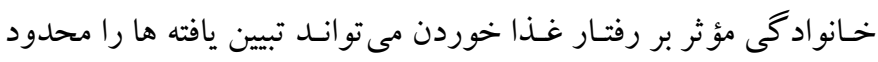

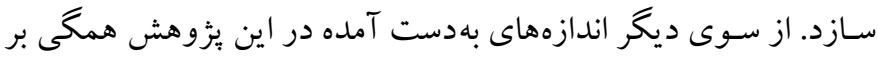

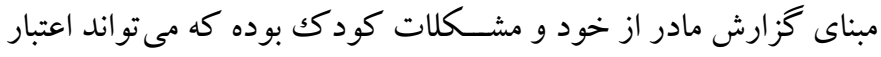

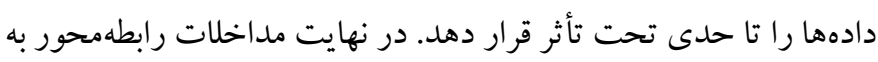

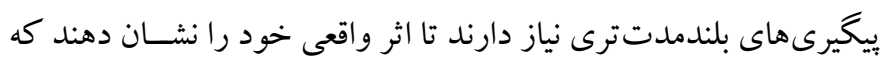
به دليل محدوديت زمانى اين كار امكان يذير نبود. بر اساس محدوديتها

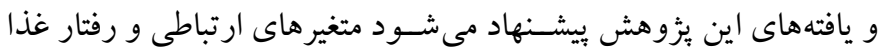
خوردن با روش هاى مشاهدهاى بر رسى شود و همبِّنين نقش ميانجى يدر

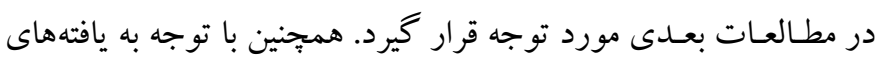

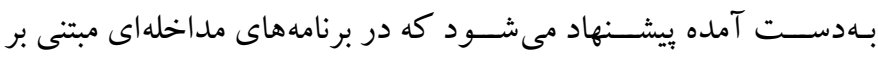
كاهش مشـكلـات خوردن كود كـان، هم از روشهاى رفتارى و هم از روشهاى مبتنى بر بهبود رابطه والد و كود كك اسـتفاده شـود تا بيشـترين اثربخشى را داشته باشد.

تشكر و قدردانى: اين مقاله بر گرفته از بايان نامه كارشـناسى ارشد خانم مهسا

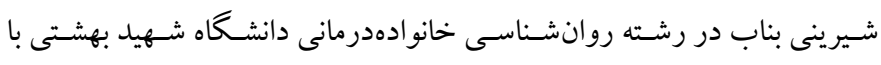

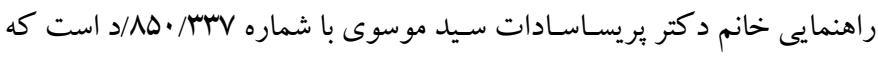

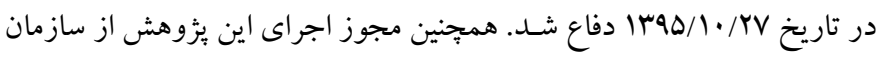

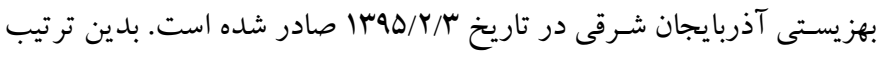
از رهنمودهاى استادان راهنما و مشاور و همكارى صميمانه مديريت و كار كنان مهدكودككهاى كيان و انديشه نو و تمامى مادران شركت كننده در اين مطالعه

$$
\text { تقدير و تشكر مىشود. }
$$

هيجانى والد و كودكى (Yr) مى تواند اين تجارب را اصلاح كند. همجنين

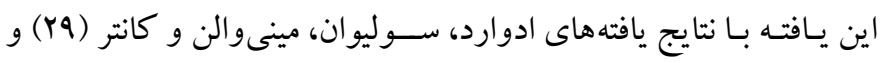

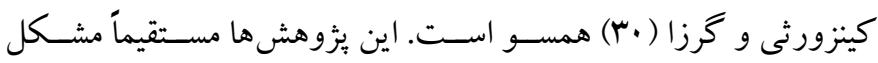

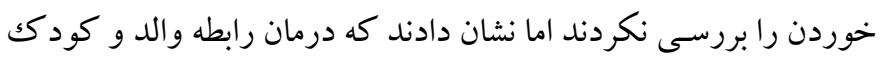
باعث بهبود مشكلات رفتارى مىشـود. درمان رابطه والد - كود كك يكك زبان جديد براى ارتباط را به مادران آموزش مىدهد و و به منظور سـاختن رابطه اسـت نه حل يكك مشـكل خاص. فرض بر اين اسـت كه با بهبود

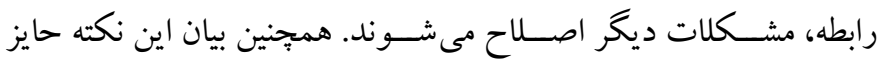

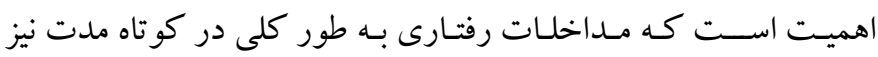
اثربخشسى خود را نشـان مى دهند در حالى كه درمان بهبود رابطه والد -

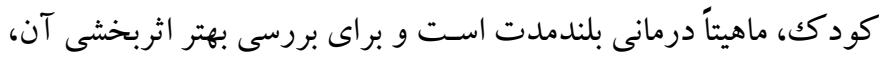

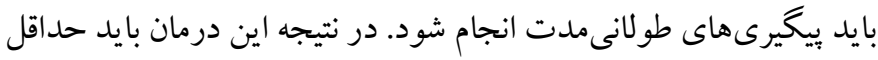

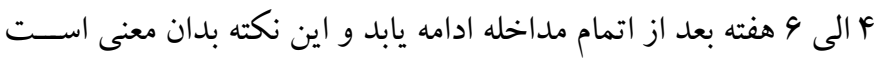

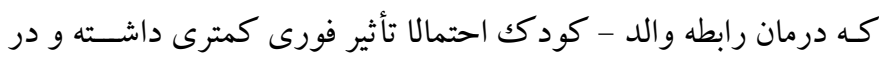
بلند مدت اثربخشى كاملى را نشـان مىدهد. از سـوى ديخر در كود كان داراى مشــكل خوردن، حتى اتر اين مشــكل در زمينهاى از مشـكلات

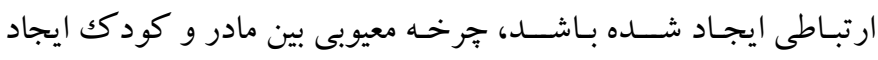

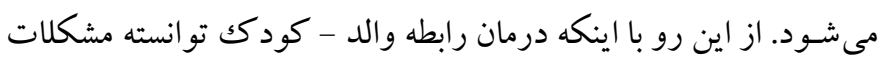
خوردن را كاهش دهد اما به نظر مىرسد برخى از اين رفتار هاى معيوب

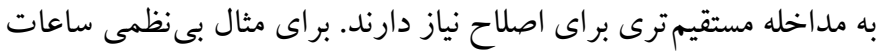

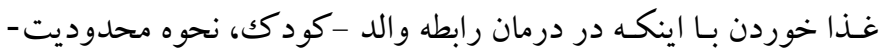
كذارى به والدين آموزش داده شده اما مستقيماً تنظيم وعده هاى غذايى،

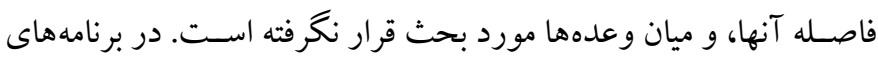

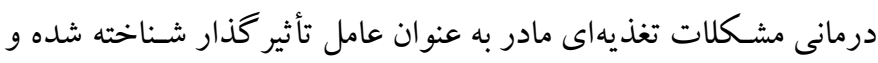
در برنـامـهـهاى افزايش كيفيت غذا خوردن بهنجار، بايد به والدين رفتار هاى مناسـبـ را آموزش داد (·r). همجنين به نظر مىرســد مشـكلات

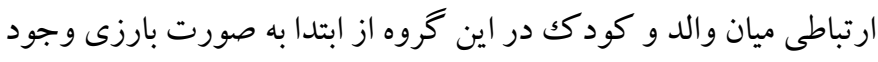

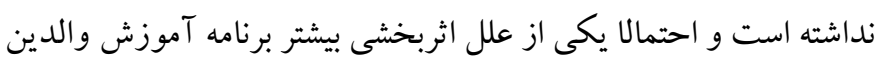

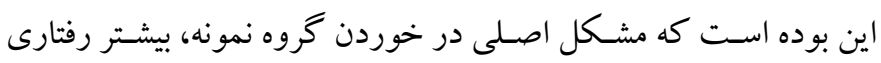
بوده است. بــه نظر مى رســــ هر دوى اين مـداخلـات مى تو انتـــــــه عنوان برنامه

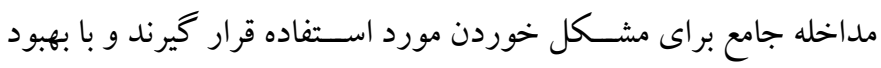




\section{References}

1. Ghasemi N, Nori L, Abdi Zarrin S. The effect of parent management training (PMT) on the reduction of behavioral symptoms in children with attention deficit hyperactivity disorder. Quarterly Journal of Child Mental Health. 2019; 6(2): 1-12. [Persian]. [Link]

2. Equit M, Pälmke M, Becker N, Moritz A-M, Becker S, Gontard A von. Eating problems in young children a population-based study. Acta Paediatr. 2013; 102(2): 149-155. [Link]

3. Kerwin ME. Empirically supported treatments in pediatric psychology: severe feeding problems. J Pediatr Psychol. 1999; 24(3): 193-214. [Link]

4. Chawner LR, Blundell-Birtill P, Hetherington MM. Interventions for increasing acceptance of new foods among children and adults with developmental disorders: a systematic review. J Autism Dev Disord. 2019; 49(9): 3504-3525. [Link]

5. Ma NS, Thompson C, Weston S. Brief report: scurvy as a manifestation of food selectivity in children with autism. J Autism Dev Disord. 2016; 46(4): 1464 1470. [Link]

6. Nicklas TA. Dietary studies of children and young adults (1973-1988): the Bogalusa heart study. Am J Med Sci. 1995; 310: 101-108? [Link]

7. Nicklas TA, Hayes D, American Dietetic Association. Position of the American Dietetic Association: nutrition guidance for healthy children ages 2 to 11 years. J Am Diet Assoc. 2008; 108(6): 1038-1044. [Link]

8. Zeinali S, Emanzadeh V, Mazaher MA, Tahmasian K, and Sadeghi MS. Efficacy of parent management training in reduction of children's feeding problems. Journal of Research and Health. 2017; 7(6): 10771085. [Persian]. [Link]

9. Benoit D, Wang EE, Zlotkin SH. Discontinuation of enterostomy tube feeding by behavioral treatment in early childhood: a randomized controlled trial. J Pediatr. 2000; 137(4): 498-503. [Link]

10. Williams KE, Riegel K, Gibbons B, Field DG. Intensive behavioral treatment for severe feeding problems: a cost-effective alternative to tube feeding? J Dev Phys Disabil. 2007; 19(3): 227-235. [Link]

11. Byars KC, Burklow KA, Ferguson K, O'Flaherty T, Santoro K, Kaul A. A multicomponent behavioral program for oral aversion in children dependent on gastrostomy feedings. J Pediatr Gastroenterol Nutr. 2003; 37(4): 473-480. [Link]

12. Cornwell SL, Kelly K, Austin L. Pediatric feeding disorders: effectiveness of multidisciplinary inpatient treatment of gastrostomy-tube dependent children. Child Health Care. 2010; 39(3): 214-231. [Link]

13. Kindermann A, Kneepkens CMF, Stok A, van Dijk EM, Engels M, Douwes AC. Discontinuation of tube feeding in young children by hunger provocation. $\mathrm{J}$ Pediatr Gastroenterol Nutr. 2008; 47(1): 87-91. [Link]

14. Silverman AH, Kirby M, Clifford LM, Fischer E, Berlin KS, Rudolph CD, et al. Nutritional and psychosocial outcomes of gastrostomy tubedependent children completing an intensive inpatient behavioral treatment program. J Pediatr Gastroenterol Nutr. 2013; 57(5): 668-672. [Link]

15. Davis AM, Bruce AS, Mangiaracina C, Schulz T, Hyman P. Moving from tube to oral feeding in medically fragile nonverbal toddlers. J Pediatr Gastroenterol Nutr. 2009; 49(2): 233-236. [Link]

16. Laud RB, Girolami PA, Boscoe JH, Gulotta CS. Treatment outcomes for severe feeding problems in children with autism spectrum disorder. Behav Modif. 2009; 33(5): 520-536. [Link]

17. Trabi T, Dunitz-Scheer M, Kratky E, Beckenbach H, Scheer PJ. Inpatient tube weaning in children with long-term feeding tube dependency: A retrospective analysis. Infant Ment Health J. 2010; 31(6): 664681. [Link]

18. Greer AJ, Gulotta CS, Masler EA, Laud RB. Caregiver stress and outcomes of children with pediatric feeding disorders treated in an intensive interdisciplinary program. J Pediatr Psychol. 2008; 33(6): 612-620. [Link]

19. Sharp WG, Jaquess DL, Morton JF, Miles AG. A retrospective chart review of dietary diversity and feeding behavior of children with autism spectrum disorder before and after admission to a daytreatment program. Focus Autism Other Dev Disabl. 2011; 26(1): 37-48. [Link]

20. Nasirzadeh R, Mazaheri MA, Ferdosi S, Nohesara S, Shahidi S. Mothers' narratives of their infants' feeding problems and comparing infant feeding styles. Journal of Kerman University of Medical Sciences. 2016; 23(1): 81-93. [Persian]. [Link] 
21. Guido CA, Zicari AM, Duse M, Spalice A. Eye movement desensitisation and reprocessing (EMDR) treatment associated with parent management training (PMT) for the acute symptoms in a patient with PANDAS syndrome: a case report. Ital J Pediatr. 2019; 45(1): 74. [Link]

22. Benjasuwantep B. Successful treatment in a child with feeding problems and growth failure. J Med Assoc Thai. 2009; 92 Suppl 3: S60-64. [Link]

23. Carnes-Holt K, Bratton SC. The efficacy of child parent relationship therapy for adopted children with attachment disruptions. J Couns Dev. 2014; 92(3): 328-337. [Link]

24. Douglas J. Psychological treatment of food refusal in young children. Child Adolesc Ment Health. 2002; 7(4): 173-180. [Link]

25. Khodaii S. play therapy. First edition. Tabriz: Ahrar; 2012, pp: 30-60. [Persian].

26. Landerth G. play therapy. Arian k (Persian translator). First edition. Tehran: Etelaat; 2000, pp: 80-100. [Persian].

27. Berk LE. Developmental through the life span. Seyyed Mohammadi Y (Persian translator). Second edition. Tehran: Arasbaran; 2000, pp: 398-399. [Persian].

28. Hicks JF, Lenard N, Brendle J. Utilizing filial therapy with deployed military families. International Journal of Play Therapy. 2016; 25(4): 210-216. [Link]

29. Edwards NA, Sullivan JM, Meany-Walen K, Kantor KR. Child parent relationship training: Parents' perceptions of process and outcome. International Journal of Play Therapy. 2010; 19(3): 159-173. [Link]

30. Kinsworthy S, Garza Y. Filial therapy with victims of family violence: a phenomenological study. J Fam Viol. 2010; 25(4): 423-429. [Link]

31. Cooper PJ, Whelan E, Woolgar M, Morrell J, Murray L. Association between childhood feeding problems and maternal eating disorder: role of the family environment. Br J Psychiatry. 2004; 184: 210-215. [Link]32. Piazza CC, Fisher WW, Brown KA, Shore BA, Patel MR, Katz RM, et al. Functional analysis of inappropriate mealtime behaviors. J Appl Behav Anal. 2003; 36(2): 187-204. [Link]

33. Turner KMT, Sanders MR, Wall CR. Behavioural parent training versus dietary education in the treatment of children with persistent feeding difficulties. Behaviour Change. 1994; 11(4): 242258. [Link]

34. Werle MA, Murphy TB, Budd KS. Broadening the parameters of investigation in treating young children's chronic food refusal. Behav Ther. 1998; 29(1): 87-104. [Link]

35. Milnes SM, Piazza CC. Intensive treatment of pediatric feeding disorders. In: Reed DD, DiGennaro Reed FD, Luiselli JK, editors. Handbook of crisis intervention and developmental disabilities. New York, NY: Springer; 2013, pp: 393-408. [Link]

36. Gulotta CS, Piazza CC, Patel MR, Layer SA. Using food redistribution to reduce packing in children with severe food refusal. J Appl Behav Anal. 2005; 38(1): 39-50. [Link]

37. Farrow CV, Galloway AT, Fraser K. Sibling eating behaviours and differential child feeding practices reported by parents. Appetite. 2009; 52(2): 307-312. [Link]

38. Bratton SC, Landreth GL. Child parent relationship therapy (CPRT): A ten session filial therapy model. New York: Routledge; 2006, pp: 15-363. [Link]

39. Hurley KM, Yousafzai AK, Lopez-Boo F. Early child development and nutrition: a review of the benefits and challenges of implementing integrated interventions1234. Adv Nutr. 2016; 7(2): 357-363. [Link]

40. Wardle J, Guthrie CA, Sanderson S, Rapoport L. Development of the children's eating behaviour questionnaire. J Child Psychol Psychiatry. 2001; 42(7): 963-970. [Link] 